\title{
Helen Salisbury: The ethics of medical memoirs
}

\author{
Helen Salisbury GP \\ Oxford
}

One of the things I like most about my job is the opportunity to learn about patients' lives: the events and incidents that have led to the current consultation, and the people involved. My timekeeping sometimes suffers because of my curiosity. When I hear surprising and interesting stories, there can be a natural urge to share them. When bad things happen, I may need to talk to my colleagues or offload on my family. But, if I do this, what is permissible?

The rules about confidentiality, when there is a risk that the person in question could be identified, are very clear. ${ }^{1}$ Even if I do not name the person, if I write about a one legged professor with an Australian accent she may easily be recognised. So, what happens if I leave out all distinguishing features so that the only person who might make a connection with the story is the patient herself?

Many medical histories are intensely personal, and the doctor may be the first person to have heard a particular story. Even if the patient will not be identified in a story (because no one else knows), she may feel very uncomfortable to discover her own life in print. And perhaps she would justifiably feel let down by that breach in confidence and may be more reticent in future consultations.

Medical memoirs are selling well at the moment, and they are undeniably fascinating. What could be more enthralling than the real life, warts and all, tales from the wards or the consulting room? The dramatic operation that saves a life or ends in tragedy, the pathos of the deathbed scene, or the gallows humour of the exhausted junior doctor (not to mention the bizarre things that patients do to themselves or to each other).

There is an avid readership for these stories; however, they make me uneasy. Even if every incident is disguised such that patients would not even recognise themselves, does this genre have a more general effect on people's trust in doctors? Would reading the current medical bestsellers make any patients less confident about talking to their doctor, fearful that their history might be written up for entertainment value at a later date?

The purpose and context make a difference as to whether it's acceptable to tell a patient's story. In teaching I often use a suitably anonymised anecdote, to illustrate concepts and to engage students. When I do talk about patients, I like to think of them as a ghost presence at my shoulder: I ask myself, would they be happy to hear me talk about them in this way? If not, then I'd better shut up.

Competing interests: See www.bmj.com/about-bmj/freelance-contributors. Provenance and peer review: Commissioned; not externally peer reviewed.

1 General Medical Council. Ethical and legal duties of confidentiality. Jan 2017. https://www. gmc-uk.org/ethical-guidance/ethical-guidance-for-doctors/confidentiality/ethical-and-legalduties-of-confidentiality.

Published by the BMJ Publishing Group Limited. For permission to use (where not already granted under a licence) please go to http://group.bmj.com/group/rights-licensing/ permissions 